\title{
Paleomagnetic reconnaissance of early Mesozoic carbonates from Williston Lake, northeastern British Columbia, Canada: evidence for late Mesozoic remagnetization'
}

\author{
Giovanni Muttoni, Dennis V. Kent, and Mike Orchard
}

\begin{abstract}
Three classic sections of Middle and Late Triassic fossiliferous limestones cropping out around Williston Lake in British Columbia, Canada, were sampled for paleomagnetic study. The objective was to test the suitability of these units for detailed magnetobiostratigraphic study with the aim of improving the reference Triassic geomagnetic polarity time scale. The Williston Lake characteristic magnetizations differ, however, from any Triassic North America cratonic reference directions. A satisfactory agreement is found instead with Cretaceous - early Cenozoic North America cratonic reference directions. The exclusive occurrence of normal polarity suggests that remagnetization likely occurred during the Cretaceous long normal superchron. Remagnetizations may have been triggered by connate brines, which moved along aquifers of porous sandstones and carbonates in the early stages of Laramide folding.
\end{abstract}

Résumé : Trois sections fossilifères classiques de calcaires (Trias moyen et tardif), affleurant autour du lac Williston en Colombie Britannique, ont été échantillonnées pour une étude paléomagnétique. L'objectif était de s'assurer de la pertinence de ces unités pour une étude magnéto-bio-stratigraphique détaillée visant à améliorer l'échelle référentielle de temps de la polarité géomagnétique au Trias. Les magnétisations caractéristiques du lac Williston diffèrent toutefois de toute direction cratonique référentielle au Trias en Amérique du Nord. Toutefois, une corrélation satisfaisante est établie avec les directions cratoniques référentielles du Crétacé-Cénozoïque précoce en Amérique du Nord.

L'occurrence exclusive d'une polarité normale suggère qu'il y eut probablement une remagnétisation au cours du long superchron normal du Crétacé. Les remagnétisations peuvent avoir été déclenchées par des saumures connées qui se sont déplacées le long d'aquifères de grès et de carbonates poreux dans les premières phases du plissement Laramide.

[Traduit par la Rédaction]

\section{Introduction}

The magnetostratigraphy and biostratigraphy of several marine and continental sedimentary sequences of Early, Middle, and Late Triassic age have been studied in recent years with the aim to construct a reference Triassic geomagnetic polarity time scale (GPTS; e.g., Ogg and Steiner 1991; Kent et al. 1995; Gallet et al. 1996, 1998; Muttoni et al. 1997). The most complete sequence of Late Triassic to earliest Jurassic magnetic polarity reversals comes from the Newark continental rift basin succession of eastern North America (Kent et al. 1995), which led to the construction of the first reliable GPTS for 30 Ma of the Late Triassic (Kent and Olsen 1999).

Triassic stage boundaries are, however, historically based on marine biostratigraphy, essentially from ammonoids and conodonts. We performed a paleomagnetic reconnaissance at three classic sections of Middle and Late Triassic marine fossiliferous limestones around Williston Lake in northeastern British Columbia. These sections have provided an integrated conodont-ammonoid biostratigraphic scale for the North America Triassic marine realm (Orchard and Tozer 1997). This study is aimed at testing the suitability of these sections for more detailed magnetostratigraphic study to correlate the marine biostratigraphic zonation to the nonmarine Newark reference GPTS.

\section{Geological setting}

Triassic rocks in the Rocky Mountains and Foothills of western Canada form a relatively thick, eastward-thinning

Received July 14, 2000. Accepted January 29, 2001. Published on the NRC Research Press Web site at http://cjes.nrc.ca on August 15, 2001.

Paper handled by Associate Editor F. Cook.

G. Muttoni. ${ }^{2}$ Institute of Geophysics, ETH-Hönggerberg, CH-8093 Zürich, Switzerland.

D.V. Kent. Lamont-Doherty Earth Observatory, Palisades, NY 10964, U.S.A., and Department of Geological Sciences, Rutgers University, Piscataway, NJ 08854, U.S.A.

M. Orchard. Geological Survey of Canada, 101-605 Robson Street, Vancouver, BC V6B 5J3, Canada.

${ }^{1}$ Lamont-Doherty Earth Observatory Contribution 6137.

${ }^{2}$ Corresponding author (e-mail: giovanni.muttoni1@unimi.it or). Present address: Dipartimento di Scienze della Terra, Universita' di Milano, Via Mangiagalli 34, I-20133 Milano, Italy. 
Fig. 1. Geographic and tectonic setting of British Columbia $(a)$ and Williston Lake area with location of sampling sites $(b)$.
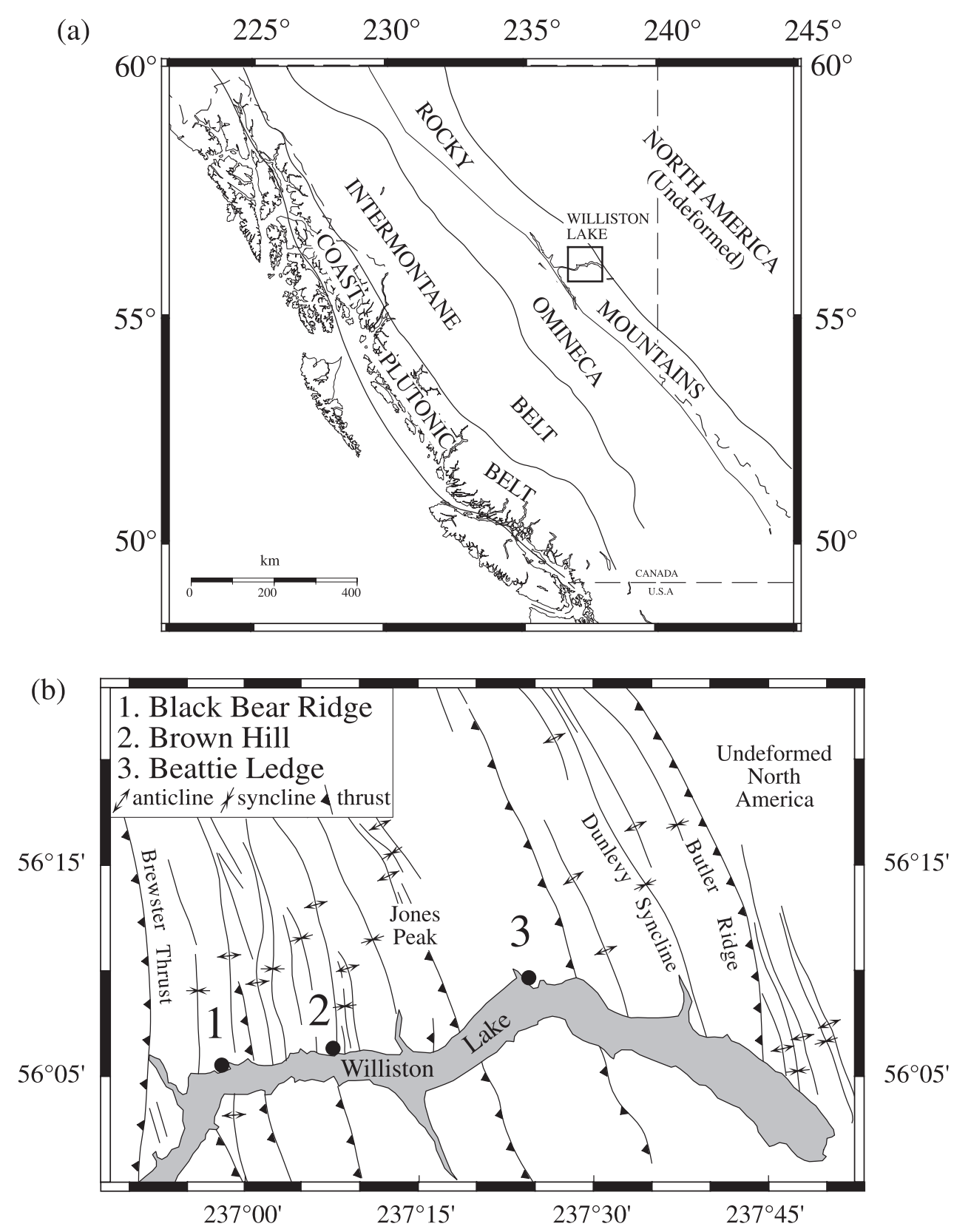

sequence of marine to marginal marine siliciclastics, carbonates, and evaporites, which form part of the Western Canada Sedimentary Basin. In northeastern British Columbia, the Triassic succession was deposited within a major cratonic embayment along the passive margin of the North American craton (Gibson and Edwards 1990). The embayment developed during Early Carboniferous and Permian time and persisted into the Triassic in response to block faulting and tectonic subsidence along the axis of the Peace River Arch (Richards 1989; Henderson 1989). During Laramide deformation in the Cretaceous and Cenozoic, this region developed as an east-vergent thrust and fold belt on the easternmost side of the Cordillera close to the main thrust that marks the exposed boundary with the undeformed North America craton (Fig. 1).

The Williston Lake area (Fig. 1b) is a reference locality that characterizes the Triassic system of the Foothills and Front Ranges of the Western Canada Sedimentary Basin. Williston Lake was created in 1967 for the generation of hydroelectric power on Peace River. As a result, many of the long-known Triassic outcrops studied since the 1920s by F.H. McLearn and later by E.T. Tozer of the Geological Survey of Canada were submerged and thus removed from further study. However, with the creation of Williston Lake, several new and unweathered Triassic rock localities became accessible along the shoreline. At these localities, Tozer (1982, 1994) collected new important Middle and Late Triassic ammonoid assemblages, and Orchard and Tozer (1997) developed an integrated conodont-ammonoid biostratigraphic scale.

The Triassic sedimentary succession in the Williston Lake area comprises eight formations, which are in ascending order the Grayling, Toad, and Liard formations of Early and 
Fig. 2. Generalized lithostratigraphic subdivision and age of the Triassic sedimentary succession in the Pine River - Williston Lake outcrop belt. The stratigraphic position of sampling localities is also reported.

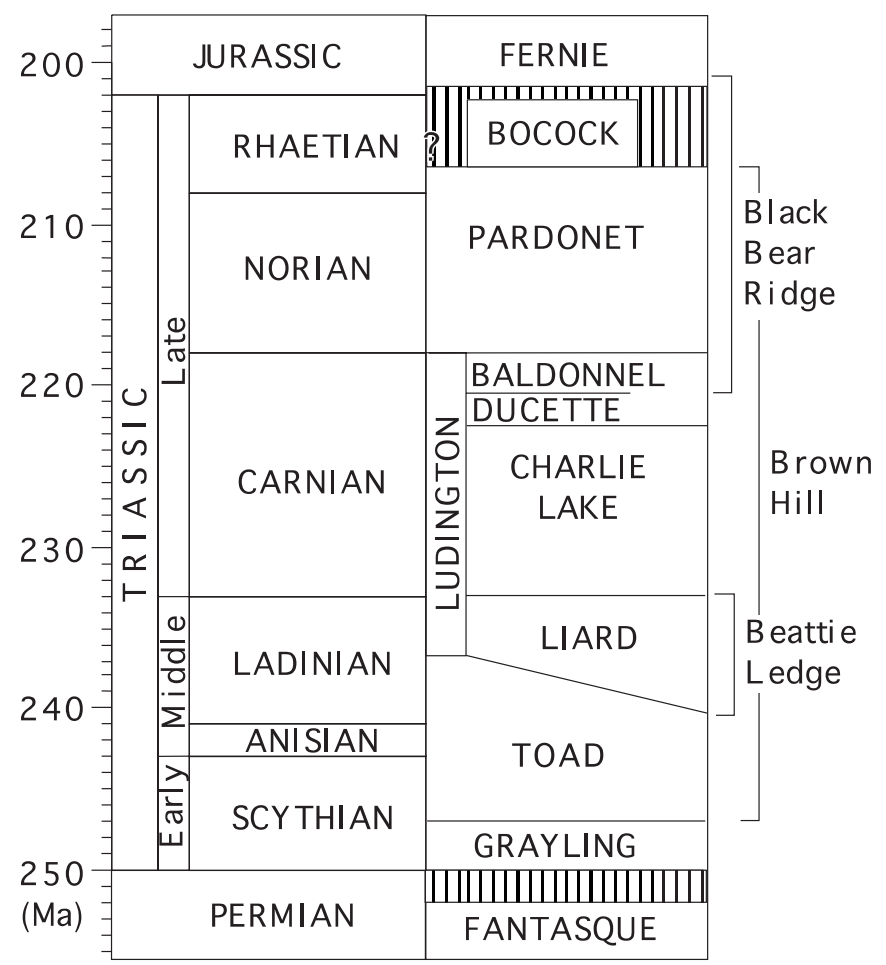

Middle Triassic age; the Charlie Lake, Baldonnel, and Ludington formations of Late Triassic (Carnian) age; and the Pardonet and Bocock formations of Late Triassic (Norian) age (McLearn and Kindle 1950; Colquhoun 1962; Gibson and Edwards 1990; Fig. 2). These Triassic rocks are overlain by the Jurassic Fernie Formation and underlain by the Permian Fantasque Formation. For further information on the stratigraphy of the Triassic succession of the Western Canada Sedimentary Basin, including the Williston Lake area, see Edwards et al. 1994 and references therein.

This region is characterized by the presence of closely spaced folds and thrusts of Triassic to Cretaceous sedimentary rocks and lies between the Brewster Thrust to the west and the Butler Ridge Thrust to the east (British Columbia Geological Survey, Map 1634A, Halfway River, scale 1 : 25 000). Deformed upper Proterozoic to Permian sediments crop out to the west of the Brewster Thrust, whereas Mesozoic and Paleozoic sediments to the east of the Butler Ridge Thrust are substantially undeformed and lie upon the North America craton. The Butler Ridge Thrust, therefore, marks the exposed boundary between the Rocky Mountain Thrust Belt and stable North America (Fig. 1b).

\section{Sampling localities}

We focused our attention on three localities located along Peace Reach on the northern shore of Williston Lake. From west to east, these localities are Black Bear Ridge, Brown Hill, and Beattie Ledge (also known as Beattie Hill; Fig. 1).

(1)The Black Bear Ridge section $\left(56^{\circ} 05^{\prime} \mathrm{N}, 236^{\circ} 58^{\prime} \mathrm{E}\right)$ is about $200 \mathrm{~m}$ thick and consists of the uppermost part of the
Fig. 3. Acquisition curves of isothermal remanent magnetization (IRM) for selected samples from the Pardonet Formation at Black Bear Ridge (BB12.2B), the Ludington Formation at Black Bear Ridge (BB1.1B), and the Liard Formation at Brown Hill (BH8B) and Beattie Ledge (BL1.2B).

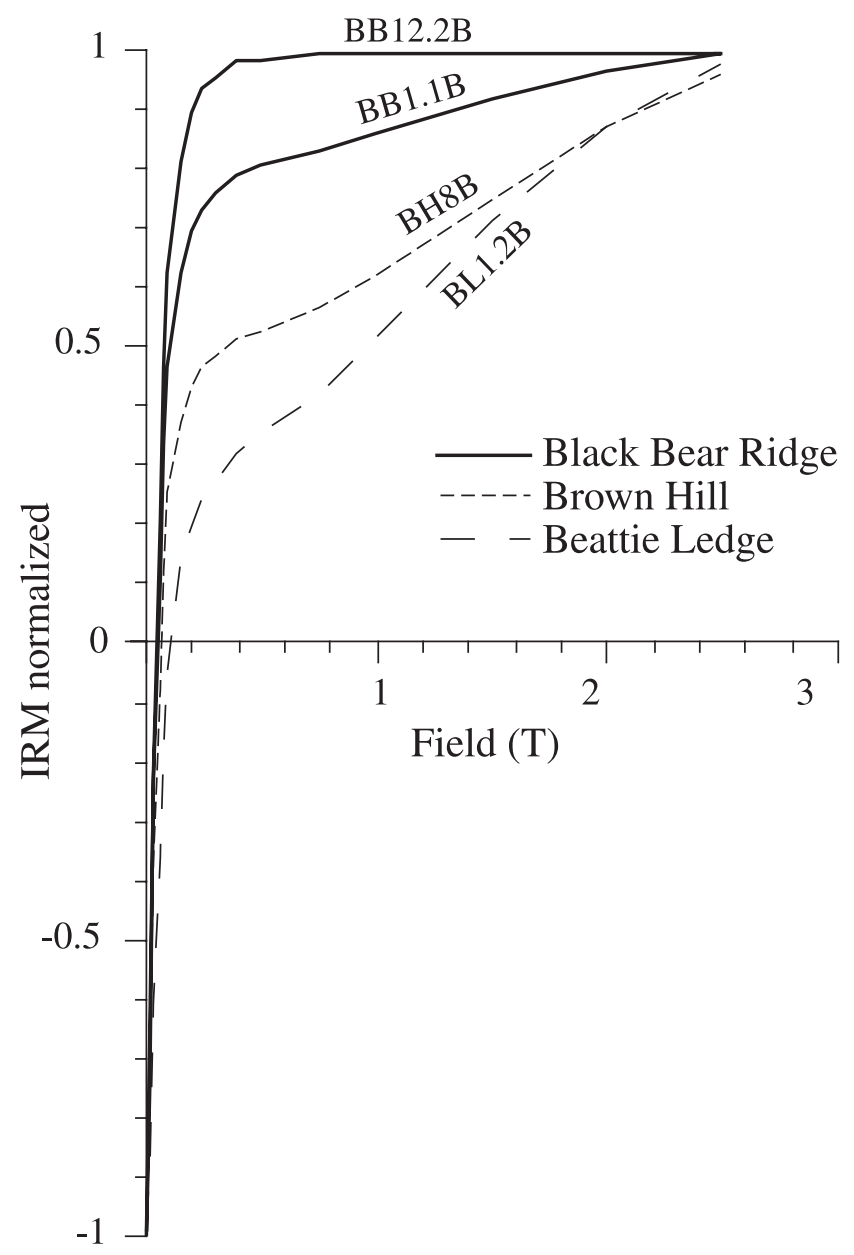

late Carnian Ludington Formation, the offshore lateral equivalent to the Baldonnel, Charlie Lake, and Liard formations, and the entire Norian Pardonet Formation, which is capped with the thin Rhaetian-age Bocock Formation and overlain by the Hettangian Fernie Formation. According to conodont biostratigraphy, the Triassic section ranges from the upper Carnian Nodosus Zone to the upper Norian Bidentata Zone. Fifteen hand samples were taken at Black Bear Ridge. The lowermost sample, BB1, was collected in the Ludington Formation, $2.5 \mathrm{~m}$ below the Pardonet Formation. The former consists of brownish-grey limestones and silty, sandy, and bioclastic limestones. The remaining samples (BB2-BB15) were distributed through the entire Pardonet Formation, which consists of dark grey to brownish-grey limestones, silty dolostones, and shales. The uppermost sample, BB15, is located within the Monotis beds of late Norian age, $30 \mathrm{~m}$ below the Triassic-Jurassic boundary (see note to Table 1 for bedding data).

(2) The Brown Hill section $\left(56^{\circ} 06^{\prime} \mathrm{N}, 237^{\circ} 07^{\prime} \mathrm{E}\right)$ consists of $790 \mathrm{~m}$ of sedimentary rocks, from the Toad Formation (Ladinian) to the Pardonet Formation of upper Norian age. Biostratigraphically, the section comprises the Mungoensis 
Fig. 4. Thermal unblocking characteristics of orthogonal-axes IRM for selected samples from the Pardonet Formation at Black Bear Ridge (BB12.2B), the Ludington Formation at Black Bear Ridge (BB1.1B), and the Liard Formation at Brown Hill (BH8B) and Beattie Ledge (BL1.2B).
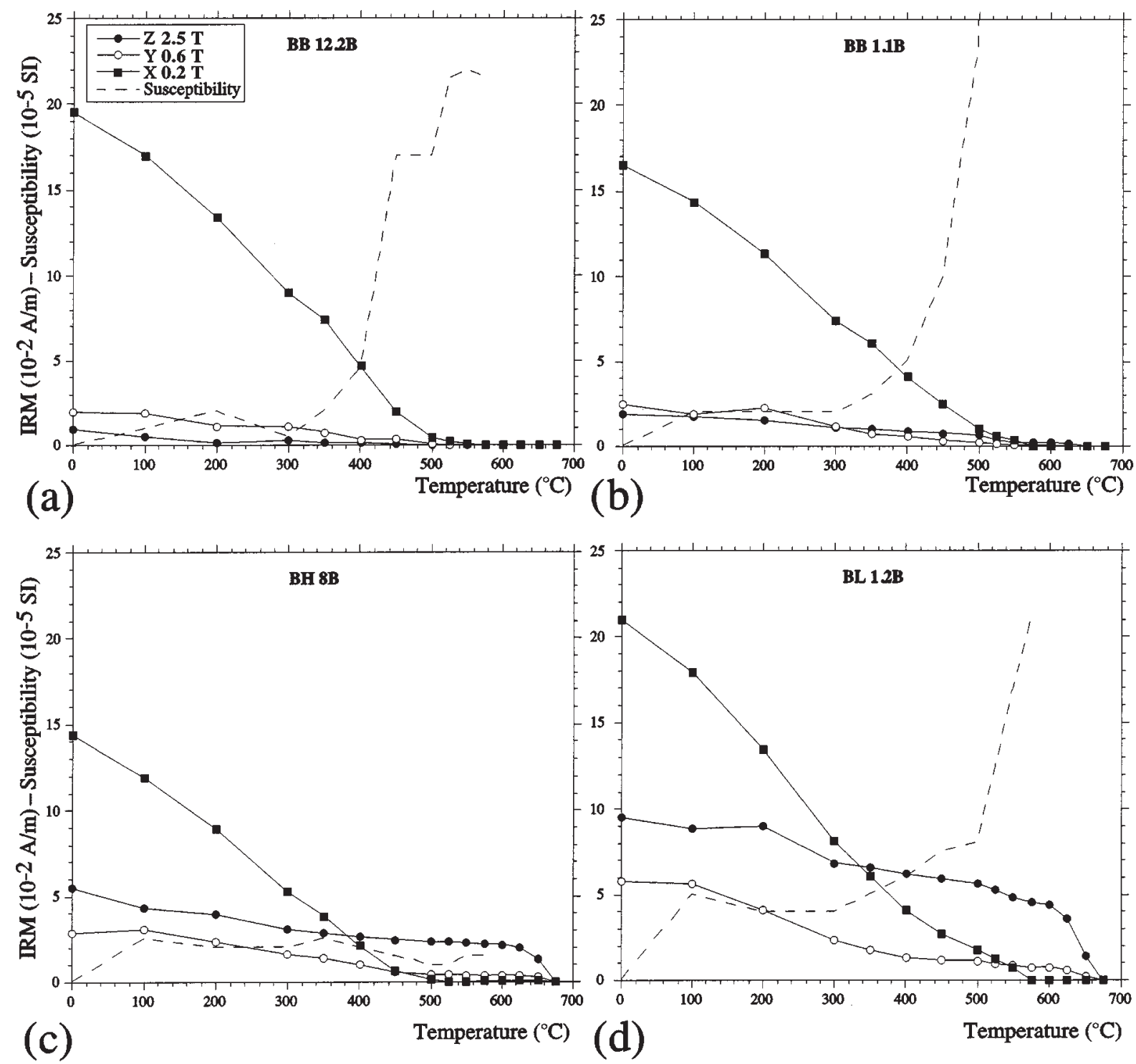

Zone (Ladinian) to the Bidentata Zone (upper Norian). The Charlie Lake Formation of Carnian age is neither well exposed nor fossiliferous and was, therefore, not sampled for paleomagnetism. Eight hand samples were taken in stratigraphic order at Brown Hill, seven in the Ladinian Toad and Liard formations (BH2, BH4, and $\mathrm{BH} 6-\mathrm{BH} 10)$, and one (BH11) in the Pardonet Formation close to the Columbianus Zone ammonoid level of middle Norian age. The Toad Formation commonly consists of dark grey to brownish grey calcareous siltstones, silty limestones, and silty shales, whereas the Liard Formation consists of grey to yellow-grey calcareous to dolomitic sandstones, siltstones, sandy to silty limestones, and bioclastic limestones.

(3) The Beattie Ledge $\left(56^{\circ} 10^{\prime} \mathrm{N}, 237^{\circ} 25^{\prime} \mathrm{E}\right)$ section, first described by McLearn (1940), is a few tens of metres thick and of stratigraphic importance for the Ladinian. It comprises the Middle Triassic Liard Formation from the Hungaricus Zone to the Mungoensis Zone and consists of decimetre-thick arenaceous to calcareous beds with a nodular base rich in ammonoids and brachiopods, followed upwards by centimetrethick, evenly bedded, finer grained siltstone and limestone beds with rare fossils. Three hand samples were taken in stratigraphic order at Beattie Ledge in the evenly bedded upper part of the section (BL1 and BL2) and in the nodular lower part (BL3).

\section{Paleomagnetism}

Hand samples yielded 43 standard $11.4 \mathrm{~cm}^{3}$ specimens from Black Bear Ridge, 17 specimens from Brown Hill, and 14 specimens from Beattie Ledge. Specimens were subjected to progressive thermal demagnetization analysis in the paleomagnetics laboratory at Lamont-Doherty using a $2 \mathrm{G}$ DC-squid cryogenic magnetometer located in a magnetically shielded room. 
Fig. 5. Representative examples of thermal demagnetization diagrams in in situ coordinates for the Pardonet Formation at Black Bear Ridge (BB12.2A), the Ludington Formation at Black Bear Ridge (BB1.1A), and the Liard Formation at Brown Hill (BH2.1A) and Beattie Ledge (BL1.1A). Solid symbols are projections onto the horizontal plane, and open symbols projections onto the vertical plane. All diagrams are in in situ coordinates.

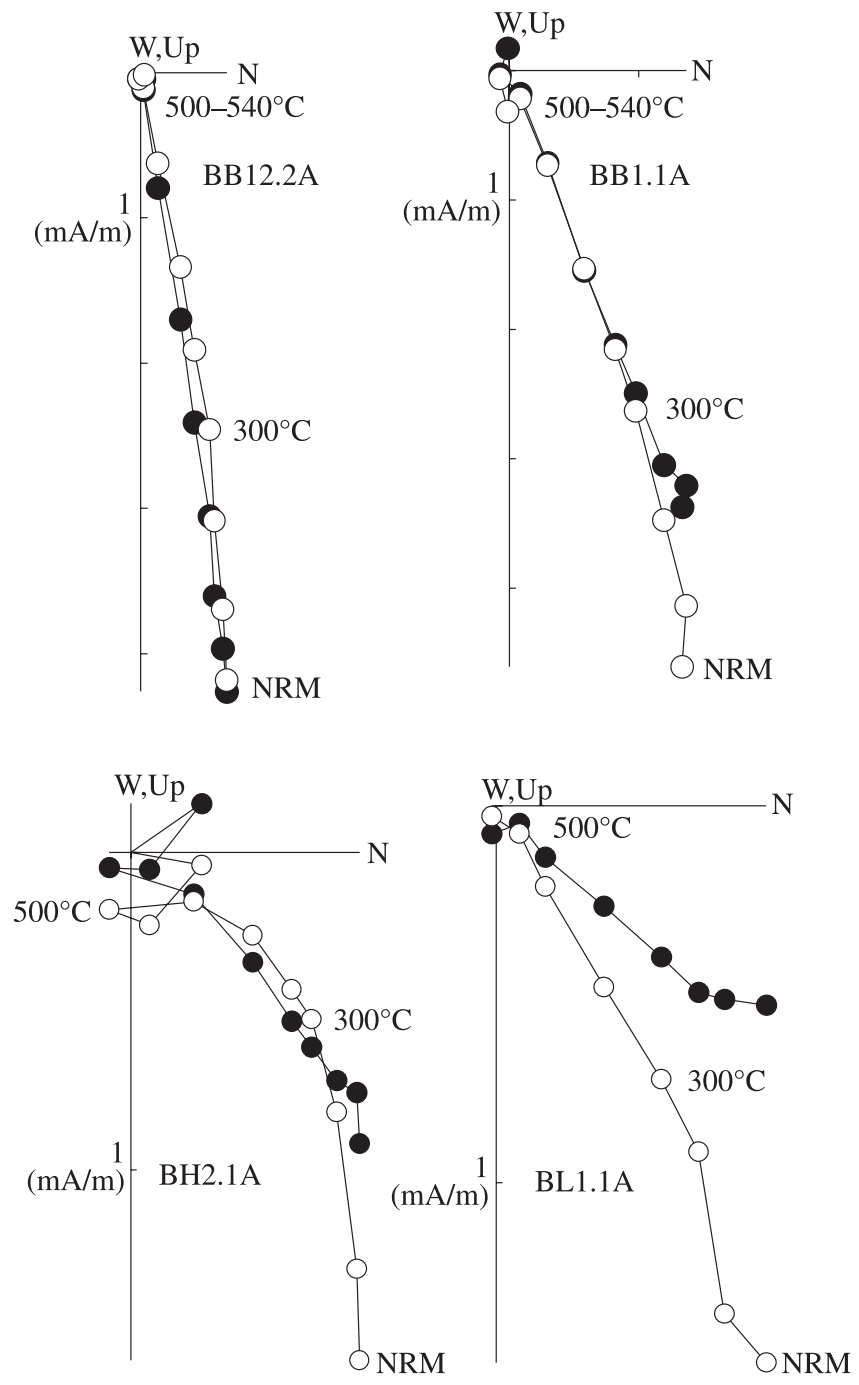

\section{Rock magnetic properties}

The intensity of the natural remanent magnetization (NRM) at Black Bear Ridge, Brown Hill, and Beattie Ledge is $6.0,3.0$, and $1.9 \mathrm{~mA} / \mathrm{m}$, respectively. The magnetic mineralogy of selected samples was determined with acquisition curves of isothermal remanent magnetization (IRM) and thermal decay of a composite IRM imparted at 2.5, 0.6, and $0.2 \mathrm{~T}$ fields along sample orthogonal axes according to the method described by Lowrie (1990). IRM acquisition curves reveal that the Pardonet Formation at Black Bear Ridge is dominated by a soft coercivity component that saturates at fields of about $0.4 \mathrm{~T}$ (Fig. 3, sample BB12.2B). The thermal unblocking characteristics of orthogonal-axes IRM show that this dominant low-coercivity magnetic phase has maximum unblocking temperatures of $500-575^{\circ} \mathrm{C}$ (Fig. $4 a$ ), suggesting
Fig. 6. Stereographic projections in in situ (geographic) and tilt-corrected coordinates of the $\mathrm{B}$ component directions isolated between 300 and $500^{\circ} \mathrm{C}$ at Black Bear Ridge, Brown Hill, and Beattie Ledge. Solid symbols refer to the lower hemisphere.

\section{In Situ Tilt Corrected} Black Bear Ridge
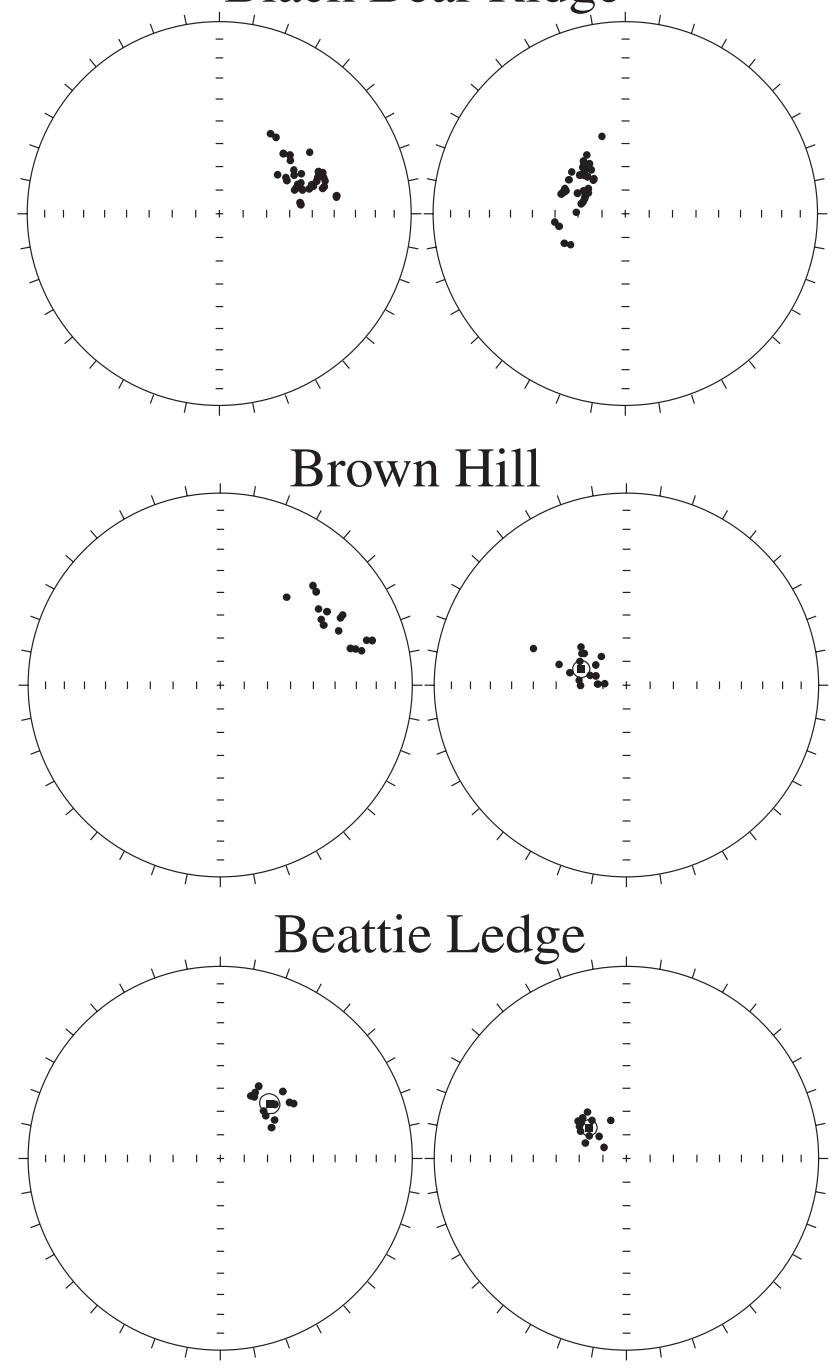

magnetite as the main carrier of the magnetic remanence. IRM acquisition curves of representative samples from the Ludington Formation at Black Bear Ridge (BB1.1B) and the Liard Formation at Brown Hill (BH8B) and Beattie Ledge (BL1.2B) reveal the presence of a soft coercivity phase, again consistent with magnetite, which variably coexists with a higher coercivity phase that does not saturate at $2.5 \mathrm{~T}$ fields (Fig. 3). Thermal decay of orthogonal IRM shows that this higher coercivity phase, mainly carried by the $2.5 \mathrm{~T}$ field curve, persists to $675^{\circ} \mathrm{C}$, and is, therefore, attributed to hematite (e.g., Figs. $4 b-4 d$ ).

\section{Paleomagnetic directions}

Progressive thermal demagnetization was applied to all remaining specimens to isolate the magnetic components of the NRM. Least-squares analysis was used to determine the component directions (Kirschvink 1980), chosen by inspection 
Table 1. Paleomagnetic directions from Williston Lake.

\begin{tabular}{|c|c|c|c|c|c|c|c|c|c|c|c|c|c|}
\hline \multirow[b]{2}{*}{ Site } & \multicolumn{2}{|c|}{ Location } & \multirow[b]{2}{*}{$N_{1}$} & \multirow[b]{2}{*}{$\mathrm{N}_{2}$} & \multirow[b]{2}{*}{$N_{3}$} & \multicolumn{4}{|c|}{ In situ } & \multicolumn{4}{|c|}{ Tilt corrected } \\
\hline & Lat. $\mathrm{N}$ & Long. E & & & & $D\left(^{\circ}\right)$ & $I\left(^{\circ}\right)$ & $k$ & $\alpha_{95}\left(^{\circ}\right)$ & $D\left(^{\circ}\right)$ & $I\left(^{\circ}\right)$ & $k$ & $\alpha_{95}\left(^{\circ}\right)$ \\
\hline Black Bear Ridge & $56^{\circ} 05^{\prime}$ & $236^{\circ} 58^{\prime}$ & 15 & 43 & 37 & 67.6 & 50.1 & Non-Fisherian & & 301.2 & 66.9 & Non-Fisherian & \\
\hline Brown Hill & $56^{\circ} 06^{\prime}$ & $237^{\circ} 07^{\prime}$ & 8 & 17 & 15 & 61.1 & 31.3 & Non-Fisherian & & 292.2 & 69.7 & 70 & 4.6 \\
\hline Beattie Ledge & $56^{\circ} 10^{\prime}$ & $237^{\circ} 25^{\prime}$ & 3 & 14 & 12 & 42.0 & 58.5 & 106 & 4.2 & 309.4 & 69.5 & 162 & 3.4 \\
\hline
\end{tabular}

Note: $N_{1}$, number of hand samples; $N_{2}$, number of standard $11.4 \mathrm{~cm}^{3}$ specimen core samples; $N_{3}$, number of paleomagnetic directions used to calculate the mean; $D$ and $I$, declination and inclination; $k$, precision parameter; $\alpha_{95}$ radius of cone of $95 \%$ confidence about the mean direction. Paleomagnetic hand samples have the following bedding orientations (azimuth of dip in degrees east of north versus dip in degrees from horizontal): Black Bear Ridge, $210^{\circ}$ to $259^{\circ} \mathrm{E} / 49^{\circ}$ to $66^{\circ}$; Brown Hill, $224^{\circ}$ to $240^{\circ} \mathrm{E} / 65^{\circ}$ to $88^{\circ}$; Beattie Ledge, $220^{\circ}$ to $236^{\circ} \mathrm{E} / 37^{\circ}$ to $44^{\circ}$.

Table 2. Paleomagnetic overall mean directions and paleopoles from Williston Lake.

\begin{tabular}{|c|c|c|c|c|c|c|c|c|c|}
\hline$\%$ unfolding & $N$ & $D\left({ }^{\circ}\right)$ & $I\left({ }^{\circ}\right)$ & $k$ & $\alpha_{95}\left(^{\circ}\right)$ & Lat. $\mathrm{N}\left({ }^{\circ}\right)$ & Long. E $\left({ }^{\circ}\right)$ & $\mathrm{dp}\left({ }^{\circ}\right)$ & $\mathrm{dm}\left({ }^{\circ}\right)$ \\
\hline 0 & 3 & 47.1 & 58.3 & 25 & 25.1 & 80.6 & 206.6 & 10.3 & 11.1 \\
\hline 72 & 3 & 349.1 & 76.2 & 417 & 6.0 & 80.6 & 206.6 & 10.3 & 11.1 \\
\hline 80 & 3 & 331.1 & 75.5 & 676 & 4.7 & 74.1 & 183.2 & 7.9 & 8.6 \\
\hline 87 & 3 & 317.9 & 73.9 & 821 & 4.3 & 67.8 & 174.8 & 7.0 & 7.8 \\
\hline 100 & 3 & 300.8 & 69.1 & 485 & 5.6 & 56.7 & 166.8 & 8.1 & 9.5 \\
\hline
\end{tabular}

Note: Poles are referred to a nominal site located at $56.1^{\circ} \mathrm{N}, 237.2^{\circ} \mathrm{E} . N$, number of site mean directions; $\mathrm{dm}$ and dp, associated errors. 
Fig. 7. (a) Stereographic projections in in situ (geographic) and tilt-corrected coordinates of the B component mean directions from Black Bear Ridge, Brown Hill, and Beattie Ledge (symbols refer to the lower hemisphere). (b) Variation of the $k_{\text {situ }} / k$ ratio and associated error (Cox 1969) upon incremental correction for bedding tilt with location of region where grouping is significant at $99 \%$ confidence level (McElhinny 1964; shaded area). The Great Circle distance and associated errors between the Williston overall mean direction at incremental correction for tilting and the Carnian (Kent and Olsen 1997) and Cretaceous (Van Fossen and Kent 1992) reference directions for stable North America are also reported. See text for discussion.

(a) In Situ Tilt Corrected
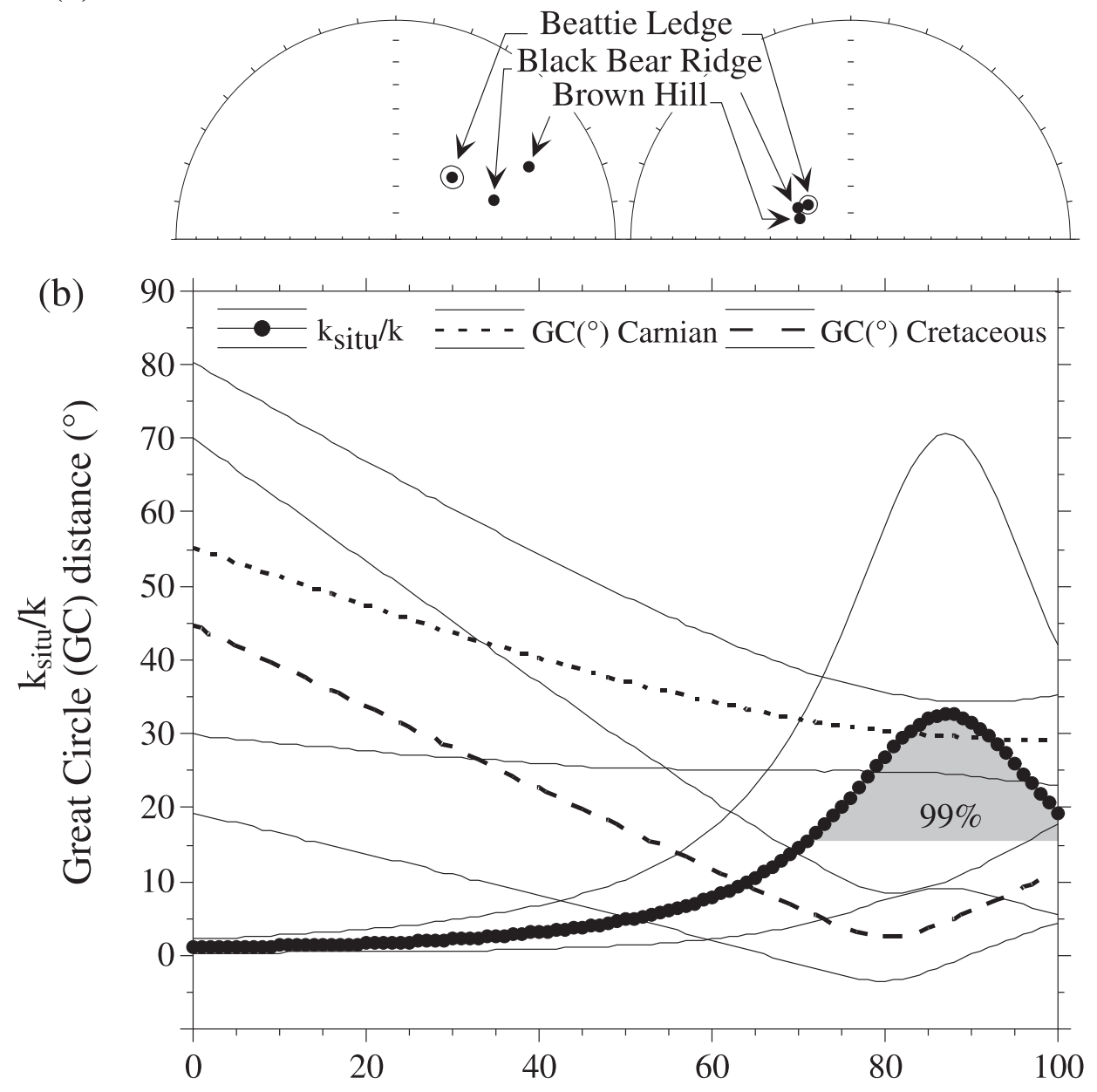

of vector end-point demagnetization diagrams (Zijderveld 1967). Site mean directions were determined on all specimens from each individual site using standard Fisher statistics. In situ demagnetization diagrams show the presence of a scattered initial "A" component isolated between the NRM and $200^{\circ} \mathrm{C}$ (Fig. 5), which is broadly consistent with acquisition along the present-day Earth's magnetic field direction (north and steeply down). A single-polarity univectorial component, hereafter referred to as the " $\mathrm{B}$ " component, was isolated in the temperature range from 300 to $500^{\circ} \mathrm{C}$ (Fig. 5). This magnetization component is oriented northeast and down in in situ coordinates or northwest and down in tilt-corrected coordinates (Fig. 6; Table 1).

The site mean B directions from Black Bear Ridge, Brown Hill, and Beattie Ledge show a statistically significant improvement in grouping between 72 and 100\% unfolding (at 99\% confidence level; McElhinny 1964; Fig. 7a, 7b). The Williston Lake overall mean direction at $87 \%$ unfolding, where grouping is best, is declination $D=317.9^{\circ}$ and
$\%$ Unfolding inclination $I=73.9^{\circ}$ (Table 2). Bracketing directions for the range of statistically significant grouping are reported in Table 2.

The peak in precision parameter $k$ at $87 \%$ unfolding suggests a secondary synfolding magnetization, although $100 \%$ unfolding is not statistically precluded and, therefore, the directions might be prefolding and possibly original. However, the Williston overall mean direction at any position between 72 and $100 \%$ unfolding is too steep to be reconciled with Triassic cratonic North America directions. The Williston mean inclinations imply paleolatitudes of $50-70^{\circ}$ compared with only about $25^{\circ}$ predicted for the area based on Late Triassic (Carnian) reference direction for stable North America (Kent and Olsen 1997). Further details of the relationship between Williston and North America reference directions are more effectively visualized in pole space.

\section{Paleopoles}

We calculate a sequence of paleopoles from the Williston 
Fig. 8. The Williston Lake B component synfolding paleopole track from 72 to $100 \%$ unfolding (solid circles) is compared with the master apparent polar wander path in North America coordinates of Besse and Courtillot (1991; open circles from 10 to $200 \mathrm{Ma}$ ), with selected Triassic paleopoles from regions of stable North America outside the Colorado Plateau (Red Peak, Scythian; Dan River - Danville, Carnian; Lower Newark, Carnian; Upper Newark, Norian; Upper Newark, Hettangian), and with Late Triassic data from the Colorado Plateau (Norian Plateau). The 124-88 Ma paleopole of Van Fossen and Kent (1992; Cretaceous Standstill pole) is also shown.

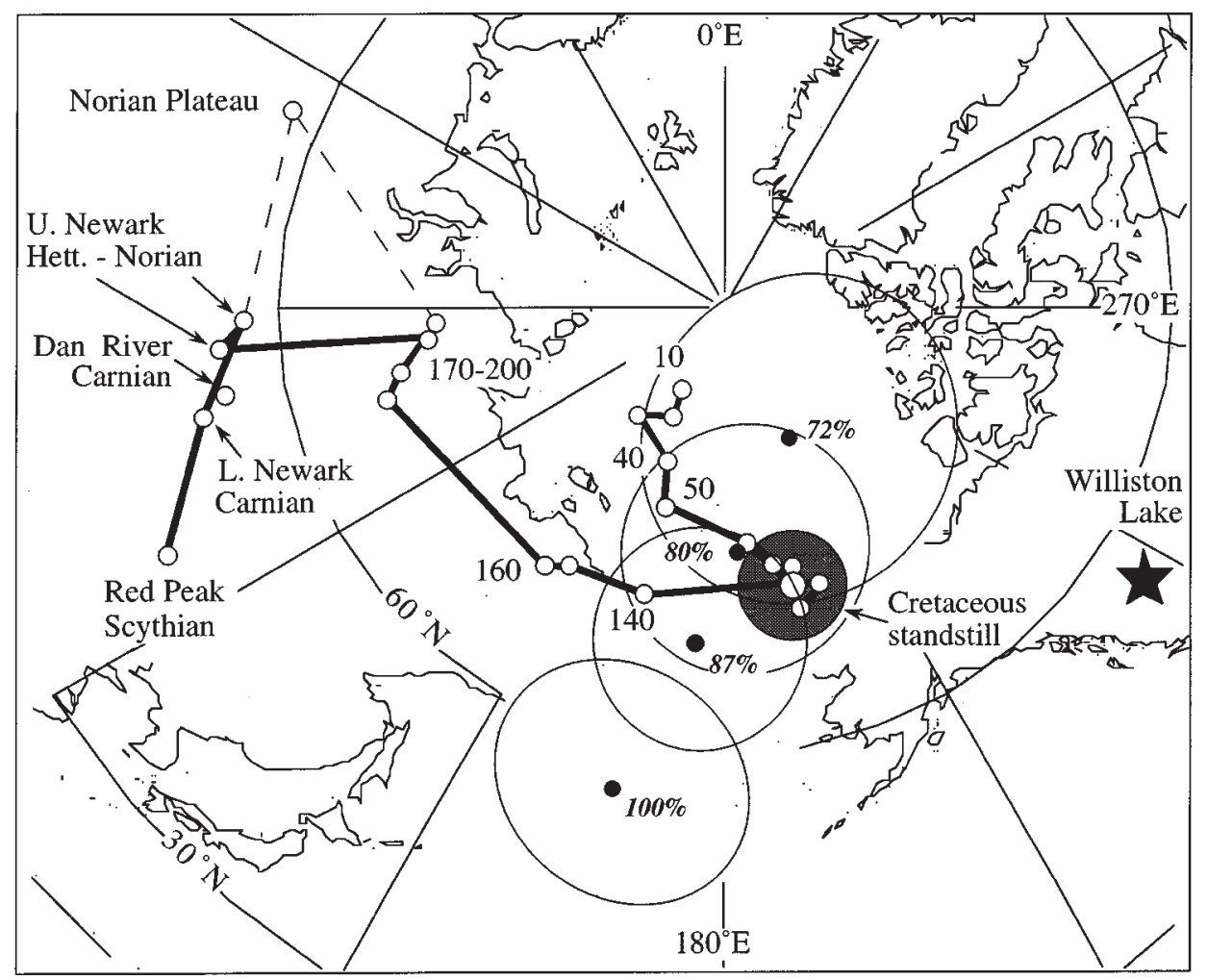

Lake overall mean direction from 72 to $100 \%$ unfolding (Table 2). These are compared with the Jurassic-Cenozoic master apparent polar wander path (APWP) in North America coordinates of Besse and Courtillot (1991) and selected Triassic reference paleopoles from North America (Kent and Witte 1993; Kent and Olsen 1997; Fig. 8).

The Williston paleopole at any degree of unfolding is far removed from Triassic North American reference paleopoles from either on or off the Colorado Plateau (Fig. 8). A southerly motion of about $3000 \mathrm{~km}$ would be required to reconcile Williston with North America Triassic cratonic paleopoles. There is no geologic or paleomagnetic evidence, however, that the Foothills and Front Ranges have ever moved northward or southward by any substantial amount, only that they have been thrust faulted east-northeast by a few tens of kilometres during Laramide deformation pulses (D.T.A. Symons, personal communication, 2000). Up to $4000 \mathrm{~km}$ of tectonic displacement in a northerly direction during the Cretaceous-Eocene has been proposed for allochthonous accreted and parautochthonous terrains of the northern Cordillera located to the west of the Foothills and Front Ranges (Irving et al. 1996 and references therein). The exclusive occurrence of normal polarity remanence directions, when the Middle and Late Triassic are characterized by two or more reversals per million years (Muttoni et al. 1997; Kent and Olsen 1999), is an additional argument against a primary origin for the Williston remanence.
The full range of statistically significant Williston paleopoles between 72 and 100\% unfolding is compatible in colatitude with the Cretaceous-Cenozoic portion of the stable North America APWP. At $72 \%$ unfolding, the Williston paleopole is rotated by $10 \pm 12^{\circ}$ clockwise with respect to the Early Cretaceous North America reference paleopole (124-88 Ma) of Van Fossen and Kent (1992; latitude $71.2^{\circ} \mathrm{N}$, longitude $194.1^{\circ} \mathrm{E}$ ), whereas at $100 \%$ unfolding the Williston paleopole is rotated by $19 \pm 10^{\circ}$ counterclockwise from this reference pole. At $87 \%$ unfolding, where directional grouping is best, the angular distance between the Williston and Cretaceous reference paleopoles is $7.5 \pm 9^{\circ}$, whereas at $80 \%$ unfolding the paleopoles are also statistically indistinguishable (Fig. 8).

We suggest that Triassic rocks at Williston Lake were remagnetized during the initial stages of the CretaceousCenozoic Laramide orogenic phase between 72 and $100 \%$ unfolding. The exclusive occurrence of normal polarity directions can then be reconciled with remanence acquisition during either the Cretaceous long normal superchron, a period of the Earth's magnetic field from about 118 to 84 Ma characterized by stable normal polarity, or perhaps one of the somewhat shorter, but still appreciable in length, normal polarity chrons in the Late Cretaceous (e.g., C33n). Large-scale dextral strike-slip faults associated with the Cretaceous-Eocene northern Cordillera tectonics in the parautochthonous-accreted terrains region to the west of the North America craton (e.g., 
Fig. 9. Map of the North America continent with location of sites remagnetized in the Cretaceous (open squares) and Carboniferous Early Permian (solid circles). Shaded areas are fold-thrust belts, and smoothed polygons are gas and oil fields (Oliver 1986, simplified). Numbers correspond to references as follows: 1, Bohnel et al. 1990; 2, Hagstrum and Sedlock 1990; 3, Hagstrum et al. 1985; 4, Hagstrum et al. 1993; 5, Hagstrum 1994; 6, Spall 1971; 7, Hagstrum 1992; 8, Gillett and Van Alstine 1982; 9, Reynolds et al. 1985; 10, Frei and Blake 1987; 11, Achache et al. 1982; 12, Russell et al. 1982; 13, Schwartz and Van der Voo 1984; 14, Bogue et al. 1989; 15, Enkin et al. 1997, Symons et al. 1998b, 1999, Gillen et al. 1999, Enkin et al. 2000, and Cioppa et al. 2000; 16, Rees et al. 1985; 17, this study; 18, Zhang et al. 1996; 19, Haeussler et al. 1992; 20, Butler et al. 1988; 21, Symons et al. 1993; 22, Wynne et al. 1998; 23, Smethurst et al. 1999; 24, Lewchuk et al. 2000. Carboniferous - Early Permian remagnetizations from the northeastern Appalachians (Newfoundland, Nova Scotia, Quebec, and Maine) are from Irving and Strong (1984), Johnson and Van der Voo (1986), Pan et al. (1993), Seguin (1986), Wellensiek et al. (1990), and Lombard et al. (1991). Remagnetizations from the central-southern Appalachians (from New York State to Alabama) are from Miller and Kent (1988 and references therein), Stamatakos et al. (1996 and references therein), and Hodych et al. (1985). Remagnetizations north of the Ouachita front are from Symons et al. (1998a) (Missouri); Ellwood and Crick (1988) and Elmore et al. (1993) (Oklahoma); Haubold (1999) (central and western Texas); and Lynnes and Van der Voo (1984) and Larson and Mutschler (1971) (Colorado).

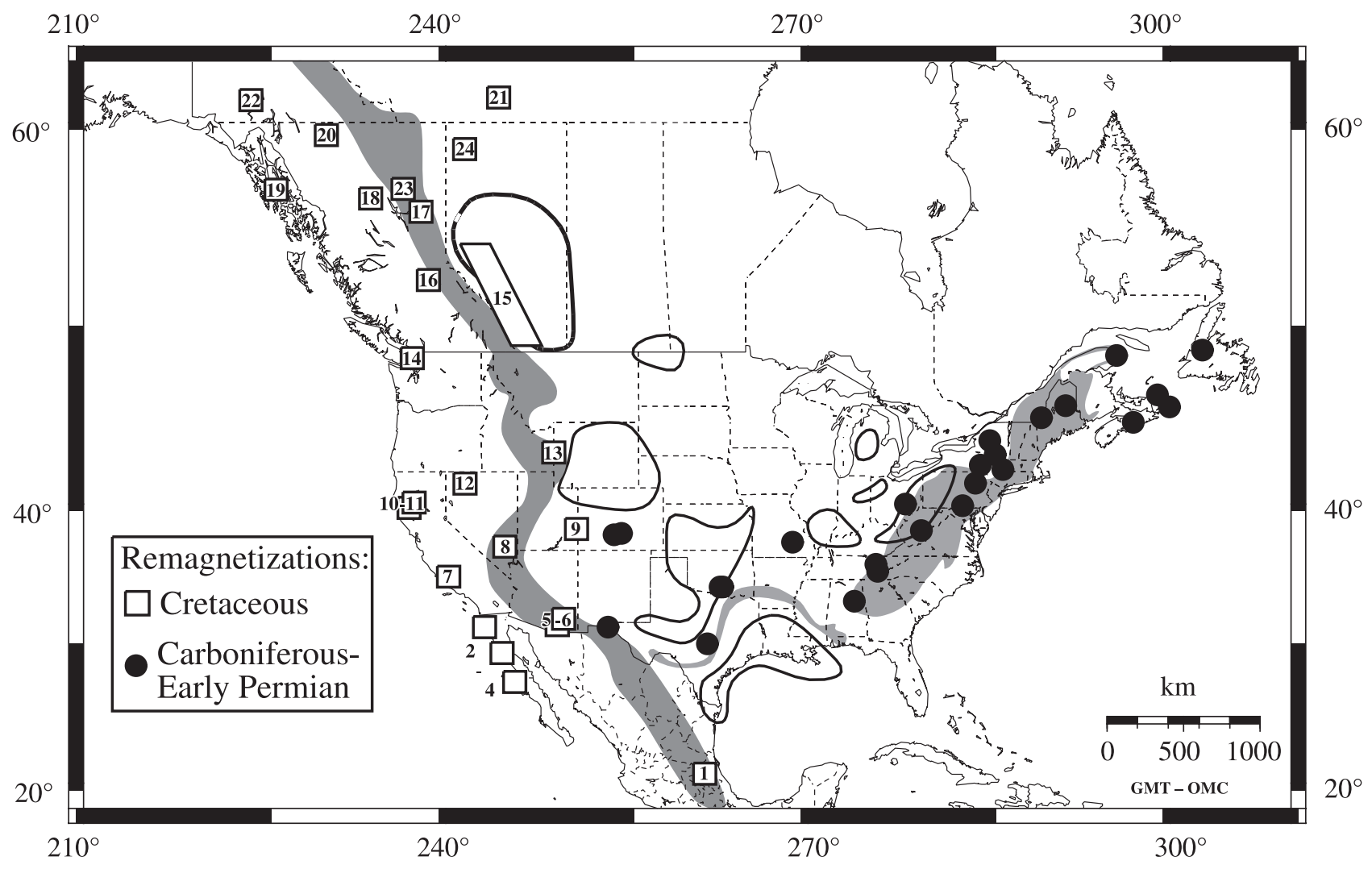

Irving et al. 1996) induced generally clockwise rotations of crustal blocks about subvertical axes, like in the McConnell Creek area to the west of Williston Lake (Zhang et al. 1996). In the Foothills and Front Ranges of the North American craton (e.g., Williston Lake), however, there seems to be no paleomagnetic evidence for any substantial amount of clockwise or counterclockwise rotation in Laramide-remagnetized rocks (e.g., Smethurst et al. 1999). This indicates that the 72 or $100 \%$ unfolding may not be the correct reference frames for calculating the Williston pole because of the clockwise or counterclockwise rotations that they would imply, respectively. Despite the uncertainty in the Williston pole position, however, it is interesting to note the occurrence of secondary, probably Cretaceous directions acquired sometime in the folding process. We compare Williston data with data from the literature and discuss the origin of what seems to be a widespread event of Cretaceous remagnetization in the North America continent (Irving et al. 1993).

\section{Cretaceous remagnetizations in North America}

In the North America continent, remagnetizations of Cretaceous age have been reported along the Rocky Mountains from Mexico (Fig. 9, locality 1) to the northern Canadian Cordillera (locality 22), up to the Northwest Territories (Park 1992) and the Brooks Range in Alaska (Hillhouse and Gromme 1983). Remagnetizations are frequently of thermoviscous or thermochemical origin (Kent 1985; Miller and Kent 1988) associated with the emplacement of batholiths or volcanic activity (localities 2-4, 10-12, 16, 18, $20,22)$ or in other ways related to Cretaceous Cordillera 
orogenic events (localities 1, 7, 8, 13, 14, 19). In the Foothills of the Rocky Mountains and in the adjacent foreland domains, remagnetizations of Cretaceous age have been specifically associated with tectonically induced migration of mineralizing fluids (localities 9, 15, 21, 24). The emplacement of thrust sheets in zones of convergence causes the expulsion of chemically active, hot fluids from the margin sediments toward the craton (Oliver 1986, 1992). These fluids are thought to play key roles in geologic phenomena, such as the distribution of hydrocarbons and ores, the variation in the rank of coals, and the growth of authigenic minerals, and were considered responsible for widespread thermochemical remagnetizations in the Appalachians during the Carboniferous - Early Permian (Miller and Kent 1988 and references therein) (Fig 9, solid circles). A similar mechanism involving fluid-flow events associated with the Laramide orogeny has been recently proposed to explain Cretaceous remagnetizations and other geological phenomena in the Western Canada Sedimentary Basin and adjacent Foothills regions (Enkin et al. 1997, 2000; Symons et al. 1998b, 1999; Gillen et al. 1999; Cioppa et al. 2000; Fig. 9, locality 15). In the Peace River Arch area, large-scale fluid flows of Late Cretaceous - early Cenozoic age moved from elevated recharge zones in the west toward the eastern flank of the Western Canada Sedimentary Basin, overprinting Precambrian-Devonian fission-track data (Issler et al. 1990). It is, therefore, possible that Triassic rocks at Williston Lake in the Peace River Arch area were also remagnetized by fluid events of the type described by Issler et al. (1990).

\section{Conclusions}

This study was aimed at obtaining magnetostratigraphic data to establish a well-dated magnetic reversal sequence in the Middle and Late Triassic classic fossiliferous localities at Williston Lake in the Peace River Arch area of northwestern British Columbia. However, all sites have been remagnetized and cannot be used for their intended purpose. Sedimentary rocks at Williston Lake bear only normal polarity magnetization when the Middle and Late Triassic have been proved to have frequent reversals (Muttoni et al. 1997; Kent et al. 1995). Williston magnetization components differ from any Triassic North America cratonic (or Colorado Plateau) reference direction, and a large-scale southerly motion would be required if they were in fact Triassic, at odds with the geological history of the northern Cordillera (Irving et al. 1996). Good agreement is found instead with Cretaceous - early Cenozoic North America cratonic directions, and the exclusive occurrence of normal polarity suggests that remagnetization may have occurred during the Cretaceous long normal superchron. Remagnetizations may have been triggered by connate brines moving eastward along aquifers of porous sandstones and carbonates (Bachu 1995) prior to or in the early stages of folding in the Rocky Mountains thrust-fold belt toward the North American craton during Laramide orogeny in the Cretaceous, as suggested also for localities elsewhere in the Western Canada Sedimentary Basin (e.g., Gillen et al. 1999). This study provides additional evidence that the North America continent was affected by large-scale remagnetizations associated with Cretaceous - early Cenozoic orogenetic events such as the Sevier and (or) Laramide in the west coast domains, complementary to the Paleozoic Alleghany orogeny in the east coast domains. The virtual absence of plate motion and, therefore, polar wander in the North America continent during the Cretaceous (the so-called "North America paleopole standstill," Fig. 8) limits the use of paleomagnetism to discriminate between remagnetizations related to the Cretaceous (e.g., Sevier) or those of the Cretaceous - early Cenozoic Laramide orogeny. On the basis of pole position analysis on ancient remagnetized rocks, however, we tend to exclude the occurrence of older remagnetizations like those possibly associated with the Antler or Sonoman orogeny of Late Devonian - Carboniferous and Permian-Triassic age, respectively. The Sevier-Laramide tectonic episode seems, therefore, to have overprinted any previous one, like in the Appalachians, the Alleghany orogeny has commonly overprinted Taconic or Acadian remagnetizations.

\section{Acknowledgments}

Timothy Tozer and David Gibson led G.M. to the field and provided useful geological material and information used in this paper.

\section{References}

Achache, J., Cox, A., and O'Hare, S. 1982. Paleomagnetism of the Devonian Kennett Limestone and the rotation of the eastern Klamath Mountains, California. Earth and Planetary Science Letters, 61: 365-380.

Bachu, S. 1995. Synthesis and model of formation - water flow, Alberta Basin, Canada. American Association of Petroleum Geologists Bulletin, 79: 1159-1178.

Besse, J., and Courtillot, V. 1991. Revised and synthetic apparent polar wander paths of the African, Eurasian, North American and Indian Plates, and true polar wander since 200 Ma. Journal of Geophysical Research, 96: 4029-4050.

Bogue, S.W., Cowan, D.S., and Garver, J.I. 1989. Paleomagnetic evidence for poleward transport of Upper Jurassic rocks in the Decatur Terrane, San Juan Islands, Washington. Journal of Geophysical Research, 94: 10415 - 10427.

Bohnel, H., Gose, W.A., Testarmata, M.M., and Noriega, G.B. 1990. Palaeomagnetic results from the southern Sierra Madre Oriental, Mexico: evidence for early Cretaceous or Laramide remagnetization? Physics of the Earth and Planetary Interiors, 64: 211-223.

Butler, R.F., Harms, T.A., and Gabrielse, H. 1988. Cretaceous remagnetization in the Sylvester Allochthon: limits to post-105 Ma northward displacement of north-central British Columbia. Canadian Journal of Earth Sciences, 25: 1316-1322.

Cioppa, M.T., Al-Aasm, I.S., Symons, D.T.A., Lewchuk, M.T., and Gillen, K.P. 2000. Correlating paleomagnetic, geochemical and petrographic evidence to date diagenetic and fluid flow events in the Mississippian Turner Valley Formation, Moose Field, Alberta, Canada. Sedimentary Geology, 131: 109-129.

Colquhoun, D.J. 1962. Triassic stratigraphy in the vicinity of Peace River Foothills, British Columbia. In Edmonton Geological Society, 4th Annual Field Trip Guidebook, pp. 57-58.

Cox, A. 1969. Confidence limits for the precision parameter $k$. Geophysical Journal of the Royal Astronomical Society, 18: 545-549.

Edwards, D.E., Barclay, J.E., Gibson, D.W., Kvill, G.E., and Halton, E. 1994. Triassic strata of the Western Canada sedimentary basin. In Geological atlas of the Western Canada sedimentary basin. 
Composed by G.D. Mossop and I. Shetsen. Canadian Society of Petroleum Geologists and Alberta Research Council, Calgary, pp. 259-276.

Ellwood, B.B., and Crick, R.E. 1988. Paleomagnetism of Paleozoic asphaltic deposits in southern Oklahoma, U.S.A. Geophysical Research Letters, 15: 436-439.

Elmore, R.D., London, D., Bagley, D., Fruit, D., and Gao, G. 1993. Remagnetization by basinal fluids: testing the hypothesis in the Viola Limestone, southern Oklahoma. Journal of Geophysical Research, 98: 6237-6254.

Enkin, R.J., Osadetz, K.G., Wheadon, P.M., and Baker, J. 1997. Paleomagnetic constraints on the tectonic history of the Foreland Belt, southern Canadian Cordillera: preliminary results. Canadian Journal of Earth Sciences, 34: 260-270.

Enkin, R.J., Osadetz, K.G., Baker, J., and Kisilevsky, D. 2000. Orogenic remagnetizations in the front ranges and inner foothills of the southern Canadian Cordillera: chemical harbinger and thermal handmaiden of Cordilleran deformation. Geological Society of America Bulletin, 112: 929-942.

Frei, L.S., and Blake, M.C. 1987. Remagnetization of the coast range ophiolite and lower part of the Great Valley sequence in northern California and southwest Oregon. Journal of Geophysical Research, 92: 3487-3499.

Gallet, Y., Besse, J., Krystyn, L., and Marcoux, J. 1996. Norian magnetostratigraphy from the Scheiblkogel section (Austria): constraint on the origin of the Antalya Nappes (Turkey). Earth and Planetary Science Letters, 140: 113-122.

Gallet, Y., Krystyn, L., and Besse, J. 1998. Upper Anisian to lower Carnian magnetostratigraphy from the Northern Calcareous Alps (Austria). Journal of Geophysical Research, 103: 605-621.

Gibson, D.W., and Edwards, D.E. 1990. An overview of Triassic stratigraphy and depositional environments in the Rocky Mountain foothills and western interior plains, Peace River arch area, northeastern British Columbia. Bulletin of Canadian Petroleum Geology, 38A: 146-158.

Gillen, K.P., Van der Voo, R., and Thiessen, J.H. 1999. Late Cretaceous - Early Tertiary remagnetization of the Devonian Swan Hills Formation recorded in carbonate cores from the Caroline Gas Field, Alberta, Canada. American Association of Petroleum Geologists Bulletin, 83: 1223-1235.

Gillett, S.L., and Van Alstine, D.R. 1982. Remagnetization and tectonic rotation of Upper Precambrian and Lower Paleozoic strata from the Desert Range, Nevada. Journal of Geophysical Research, 87: 10929 - 10953.

Haeussler, P., Coe, R.S., and Onstott, T.C. 1992. Paleomagnetism of the Late Triassic Hound Island volcanics: revisited. Journal of Geophysical Research, 97: 19617 - 19639.

Hagstrum, J.T. 1992. Remagnetization of the coast range ophiolite at Stanley Mountain, California, during accretion near $10^{\circ} \mathrm{N}$ paleolatitude. Geology, 20: 503-506.

Hagstrum, J.T. 1994. Remagnetization of Jurassic volcanic rocks in the Santa Rita and Patagonia Mountains, Arizona: implications for North American apparent polar wander. Journal of Geophysical Research, 99: 15103 - 15113.

Hagstrum, J.T., and Sedlock, R.L. 1990. Remagnetization and northward translation of Mesozoic red chert from Cedros Island and the San Benito Islands, Baja California, Mexico. Geological Society of America Bulletin, 102: 983-991.

Hagstrum, J.T., McWilliams, M., Howell, D.G., and Gromme, C.S. 1985. Mesozoic paleomagnetism and northward translation of the Baja California Peninsula. Geological Society of America Bulletin, 96: 1077-1090.

Hagstrum, J.T., Martinez, M.L., and York, D. 1993. Paleomagnetic and ${ }^{40} \mathrm{Ar} /{ }^{39} \mathrm{Ar}$ evidence for remagnetization of Mesozoic oceanic rocks on the Vizcaino Peninsula, Baja California Sur, Mexico. Geophysical Research Letters, 20: 1831-1834.

Haubold, H. 1999. Alteration of magnetic properties of Palaeozoic platform carbonate rocks during burial diagenesis (Lower Ordovician sequence, Tex., U.S.A.). In Palaeomagnetism and diagenesis in sediments. Edited by D.H. Tarling and P. Turner. Geological Society Special Publication (London), pp. 181-203.

Henderson, C.M.B. 1989. Absaroka Sequence; the lower Absaroka Sequence; Upper Carboniferous and Permian. In Western Canada sedimentary basin; a case history. Edited by B.D. Ricketts. Canadian Society of Petroleum Geologists, Calgary, Alta., pp. 203-217.

Hillhouse, J.W., and Gromme, C.S. 1983. Paleomagnetic studies and the hypothetical rotation of Arctic Alaska. Alaska Geological Society Journal, 2: 27-39.

Hodych, J.P., Patzold, R.R., and Buchan, K.L. 1985. Chemical remanent magnetization due to deep-burial diagenesis in oolitic hematite-bearing ironstones of Alabama. Physics of the Earth and Planetary Interiors, 37: 261-284.

Irving, E., and Strong, D.F. 1984. Paleomagnetism of the Early Carboniferous Deer Lake Group, western Newfoundland: no evidence for carboniferous displacement of "Acadia." Earth and Planetary Science Letters, 69: 379-390.

Irving, E., Wynne, P.J., and Globermann, B.R. 1993. Cretaceous paleolatitudes and overprints of North American Craton. In Evolution of the Western Interior Basin. Edited by W.G.E. Caldwell and E.G. Kauffmann. Geological Association of Canada, Special Paper, pp. 91-96.

Irving, E., Wynne, P.J., Thorkelson, D.J., and Schiarizza, P. 1996. Large (1000 to $4000 \mathrm{~km})$ northward movements of tectonic domains in the northern Cordillera, 83 to $45 \mathrm{Ma}$. Journal of Geophysical Research, 101: 17901 - 17916.

Issler, D.R., Beaumont, C., Willett, S.D., Donelick, R.A., Mooers, J., and Grist, A. 1990. Preliminary evidence for apatite fissiontrack data concerning the thermal history of the Peace River arch region, Western Canada Sedimentary Basin. Bulletin of Canadian Petroleum Geology, 38A: 250-269.

Johnson, R., and Van der Voo, R. 1986. Paleomagnetism of the Late Precambrian Fourchu Group, Cape Breton Island, Nova Scotia. Canadian Journal of Earth Sciences, 23: 1673-1685.

Kent, D.V. 1985. Thermoviscous remagnetization in some Appalachian Limestones. Geophysical Research Letters, 12: 805-808.

Kent, D.V., and Olsen, P.E. 1997. Paleomagnetism of Upper Triassic continental sedimentary rocks from the Dan River - Danville rift basin (eastern North America). Geological Society of America Bulletin, 109: 366-377.

Kent, D.V., and Olsen, P.E. 1999. Astronomically tuned geomagnetic polarity time scale for the Late Triassic. Journal of Geophysical Research, 104: 12831 - 12841.

Kent, D.V., and Witte, W.K. 1993. Slow apparent polar wander for North America in the Late Triassic and large Colorado Plateau Rotation. Tectonics, 12: 291-300.

Kent, D.V., Olsen, P.E., and Witte, W.K. 1995. Late Triassic - earliest Jurassic geomagnetic polarity sequence and paleolatitudes from drill cores in the Newark rift basin, eastern North America. Journal of Geophysical Research, 100: 14965 - 14998.

Kirschvink, J.L. 1980. The least-squares line and plane and the analysis of palaeomagnetic data. Geophysical Journal of the Royal Astronomical Society, 62: 699-718.

Larson, E.E., and Mutschler, F.E. 1971. Anomalous paleomagnetic pole from isotopically dated Cambro-Ordovician intrusives in Colorado. Geological Society of America Bulletin, 82: 1657-1666.

Lewchuk, M.T., Al-Aasm, I.S., Symons, D.T.A., and Gillen, K.P. 2000. Late Laramide dolomite recrystallization of the Husky 
Rainbow "A" hydrocarbon Devonian reservoir, northwestern Alberta, Canada: paleomagnetic and geochemical evidence. Canadian Journal of Earth Sciences, 37: 17-29.

Lombard, A.D., van der Pluijm, B.A., and Van der Voo, R. 1991. Acadian and Alleghenian remagnetization of the Jim Pond Formation, central western Maine, northern Appalachians. Tectonophysics, 186: 279-291.

Lowrie, W. 1990. Identification of ferromagnetic minerals in a rock by coercivity and unblocking temperature properties. Geophysical Research Letters, 17: 159-162.

Lynnes, C.S., and Van der Voo, R. 1984. Paleomagnetism of the Cambro-Ordovician McClure Mountain alkalic complex, Colorado. Earth and Planetary Science Letters, 71: 163-172.

McElhinny, M.W. 1964. Statistical significance of the fold test in palaeomagnetism. Geophysical Journal of the Royal Astronomical Society, 8: 338-340.

McLearn, F.H. 1940. Triassic of Beattie Hill, Peace River Foothills, B.C. Canadian Field Naturalist, 54: 79-82.

McLearn, F.H., and Kindle, E.D. 1950. Geology of northeastern British Columbia. Geological Survey of Canada, Memoir 259.

Miller, J.D., and Kent, D.V. 1988. Regional trends in the timing of Alleghenian remagnetization in the Appalachians. Geology, 16: $588-591$.

Muttoni, G., Kent, D.V., Brack, P., Nicora, A., and Balini, M. 1997. Middle Triassic magneto-biostratigraphy from the Dolomites and Greece. Earth and Planetary Science Letters, 146: $107-120$.

Ogg, J.G., and Steiner, M.B. 1991. Early Triassic magnetic polarity time scale - integration of magnetostratigraphy, ammonite zonation and sequence stratigraphy from stratotype sections (Canadian Arctic Archipelago). Earth and Planetary Science Letters, 107: 69-89.

Oliver, J. 1986. Fluids expelled tectonically from orogenic belts: their role in hydrocarbon migration and other geologic phenomena. Geology, 14: 99-102.

Oliver, J. 1992. The spots and stains of plate tectonics. Earth-Science Reviews, 32: 77-106.

Orchard, M., and Tozer, E.T. 1997. Triassic conodont biochronology, its calibration with the ammonoid standard, and a biostratigraphic summary for the Western Canada Sedimentary Basin. Bulletin of Canadian Petroleum Geology, 45: 675-692.

Pan, H., Symons, D.T.A., and Sangster, D.F. 1993. Paleomagnetism of the Gays River zinc-lead deposit, Nova Scotia: Pennsylvanian ore genesis. Geophysical Research Letters, 20: 1159-1162.

Park, J.K. 1992. Paleomagnetism of units P1-P3 of the Late Precambrian Shaler Group, Brock Inlier, Northwest Territories. In Current research, part C. Geological Survey of Canada, Paper 92-1C, pp. 43-52.

Rees, C.J., Irving, E., and Brown, R.L. 1985. Secondary magnetization of Triassic-Jurassic volcaniclastic rocks of the Quesnel Terrane, Quesnel Lake, B.C. Geophysical Research Letters, 12: 498-501.

Reynolds, R.L., Hudson, M.R., Fishman, N.S., and Campbell, J.A. 1985. Paleomagnetic and petrologic evidence bearing on the age and origin of uranium deposits in the Permian Cutler Formation, Lisbon Valley, Utah. Geological Society of America Bulletin, 96: 719-730.

Richards, B.C. 1989. Upper Kaskaskia Sequence; Uppermost Devonian and Lower Carboniferous. In Western Canada Sedimentary Basin; a case history. Edited by B.D. Ricketts. Canadian Society of Petroleum Geologists, Calgary, Alta., pp. 165-201.

Russell, B.J., Beck, M.E., Burmester, R.F., and Speed, R.C. 1982. Cretaceous magnetizations in northwestern Nevada and tectonic implications. Geology, 10: 423-428.
Schwartz, S.Y., and Van der Voo, R. 1984. Paleomagnetic study of thrust sheet rotation during foreland impingement in the Wyoming-Idaho overthrust belt. Journal of Geophysical Research, 89: 10077 - 10086.

Seguin, M.K. 1986. Palaeomagnetism of Lower Devonian units from Gaspé, Quebec. Earth and Planetary Science Letters, 78: $129-138$.

Smethurst, M.T., Symons, D.T.A., Sangster, D.F., and Lewchuk, M.T. 1999. Paleomagnetic age for $\mathrm{Zn}-\mathrm{Pb}$ mineralization at Robb Lake, northeastern British Columbia. Bulletin of Canadian Petroleum Geology, 47: 548-555.

Spall, H. 1971. Paleomagnetic evidence for a Cretaceous disturbing event in the Precambrian Johnny Lyon Granodiorite, Cochise County, Arizona. Journal of Geology, 79: 118-122.

Stamatakos, J., Hirt, A.M., and Lowrie, W. 1996. The age and timing of folding in the central Appalachians from paleomagnetic results. Geological Society of America Bulletin, 108: 815-829.

Symons, D.T.A., Pan, H., Sangster, D.F., and Jowett, E.C. 1993. Paeomagnetism of the Pine Point $\mathrm{Zn}-\mathrm{Pb}$ deposits. Canadian Journal of Earth Sciences, 30: 1028-1036.

Symons, D.T.A., Lewchuk, M.T., and Leach, D.L. 1998a. Age and duration of the Mississippi Valley-type mineralizing fluid flow event in the Viburnum Trend, southeast Missouri, U.S.A., derived from paleomagnetism. In Dating and duration of fluid flow and fluid-rock interaction. Edited by Parnell-John. Geological Society Special Publication (London), No. 144, pp. 27-39.

Symons, D.T.A., Lewchuk, M.T., and Sangster, D.F. 1998b. Laramide orogenic fluid flow into the Western Canada Sedimentary Basin: evidence from paleomagnetic dating of the Kicking Horse Mississippi Valley-type ore deposit. Economic Geology, 93: 68-83.

Symons, D.T.A., Enkin, R.J., and Cioppa, M.T. 1999. Paleomagnetism in the Western Canada Sedimentary Basin: dating fluid flow and deformation events. Bulletin of Canadian Petroleum Geology, 47: 534-547.

Tozer, E.T. 1982. Late Triassic (upper Norian) and earliest Jurassic (Hettangian) rocks and ammonoid faunas, Halfway River and Pine Pass map areas, British Columbia. In Current research, part A. Geological Survey of Canada, Paper 82-1A, pp. 385-391.

Tozer, E.T. 1994. Canadian Triassic ammonoid faunas. Geological Survey of Canada, Bulletin 467.

Van Fossen, M.C., and Kent, D.V. 1992. Paleomagnetism of 122 Ma plutons in New England and the Mid-Cretaceous paleomagnetic field in North America: True polar wander or large-scale differential mantle motion? Journal of Geophysical Research, 97: 19651 - 19661 .

Wellensiek, M.R., van der Pluijm, B.A., Van der Voo, R., and Johnson, R.J.E. 1990. Tectonic history of the Lunksoos composite terrane in the Maine Appalachians. Tectonics, 9: 719-734.

Wynne, P.J., Enkin, R.J., Baker, J., Johnston, S.T., and Hart, C.J.R. 1998. The big flush: paleomagnetic signature of a $70 \mathrm{Ma}$ regional hydrothermal event in displaced rocks of the northern Canadian Cordillera. Canadian Journal of Earth Sciences, 35: 657-671.

Zhang, G., Hynes, A., and Irving, E. 1996. Block rotations along the strike-slip Finlay-Ingenika fault, north-central British Columbia: implications for paleomagnetic and tectonic studies. Tectonics, 15: 272-287.

Zijderveld, J.D.A. 1967. A.C. demagnetization of rocks-analysis of results. In Methods in paleomagnetism. Edited by D.W. Collinson, K.M. Creer, and S.K. Runcorn. Elsevier, New York, pp. 254-286. 